\title{
Effect of transplanting and direct sowing on productive properties and earliness of sweet corn
}

\author{
Teofil Gavrić $^{1 *}$ and Omer Omerbegović ${ }^{1}$
}

${ }^{1}$ University of Sarajevo, Faculty of Agriculture and Food Sciences, Zmaja od Bosne 8, 71000 Sarajevo, Bosnia and Herzegovina. "Corresponding author (t.gavric@ppf.unsa.ba).

Received: 7 July 2020; Accepted: 28 September 2020; doi:10.4067/S0718-58392021000100039

\begin{abstract}
Sweet corn (Zea mays L. var. saccharata [Sturtev.] L.H. Bailey) is a thermophilic crop that is sensitive to cold stress and thus may be cultivated by raising seedlings. The aim of this work was to determine the impact of transplanting and direct sowing on the yield and earliness of the sweet corn crop. The treatment protocol used had a combination of two different cultivation technologies (transplanting and direct sowing) and two different sowing periods (8 and 15 May during both growing seasons). The results show that the different cultivation technologies both had significant effects on the productive properties and earliness of sweet corn. The transplanting variants had about $34 \%$ more plants per hectare compared with the direct sowing yield. The ear length and mass were higher in crops grown using transplanting (22.2 $\mathrm{cm}$ and $278.0 \mathrm{~g}$, respectively) than in crops grown using direct sowing $(21.2 \mathrm{~cm}$ and $270.3 \mathrm{~g}$, respectively). During the research period, a significantly higher ear yield was noted in the transplanted variants $\left(11.7 \mathrm{t} \mathrm{ha}^{-1}\right)$ compared with those of direct sowing $\left(7.6 \mathrm{t} \mathrm{ha}^{-1}\right)$. The transplanting variants had earlier harvests by 18 and $16 \mathrm{~d}$ in the first and second sowing periods, respectively, compared with those of direct sowing.
\end{abstract}

Key words: Cultivation technology, direct sowing, sweet corn, transplanting, yield, Zea mays.

\section{INTRODUCTION}

Sweet corn (Zea mays L. var. saccharata [Sturtev.] L.H. Bailey) is one variety of corn whose morphological characteristics and cultivation technology are generally similar to those of other varieties -with some differences. Compared with other corn varieties, sweet corn has a kernel rich in protein, fat, and sugar (Budak and Aydemir, 2018) that is soft, juicy, sweet, and very tasty at the milk stage (Ugur and Maden, 2015). Given these characteristics, the kernels are consumed fresh or processed (Rattin et al., 2018).

Sweet corn is a thermophilic crop with an optimum growth temperature range of $21-27{ }^{\circ} \mathrm{C}$ (Mao et al., 2017; Hacisalihoglu et al., 2018). Cold temperatures $\left(<10^{\circ} \mathrm{C}\right)$ can hinder growth and can damage plants. The growing demand for sweet corn in recent years (Ugur and Maden, 2015) has resulted in the expansion of sweet corn production to regions with less-than-optimal temperatures for growth. Sweet corn cultivation in such regions results in low and variable yields.

Furthermore, increasing consumer demand requires extending the supply of fresh sweet corn beyond the conventional season, which is challenging because the quality of the kernel deteriorates rapidly after the milk stage (Alan et al., 2014). Currently, the most common method to solve this problem and extend the harvest time is to sow sweet corn earlier or later than the conventional sowing time. Sometimes, however, inadequate sowing time can cause the sweet corn crop to be exposed to various abiotic stresses. Sowing early in spring exposes the crop to cold stress, which leads to low seed germination and a reduced number of plants per hectare (Hassell et al., 2003; El-Hamed et al., 2012). While sweet corn grown at a later sowing period is susceptible to various diseases and insects (Williams, 2008) and is exposed to drought and heat stress (Heshemi et al., 2017; Tabakovic et al., 2020). 
To avoid cold stress, sweet corn may be cultivated by raising the seedlings in a greenhouse, after which they can be transplanted in the field during the most favourable weather conditions. Transplanting is commonly used in vegetable cultivation; the benefits of this practice are more uniform crops, better crop stand, and higher and more stable yield (Adesina et al., 2014). However, some species, including corn, are regarded as difficult to transplant because of a lower rate of root regeneration after transplanting (Aguyoh et al., 1999). Nonetheless, several researchers have studied sweet corn transplantation (Welbaum et al., 2001; Di Benedetto and Rattin, 2008; Andonova, 2014; Céccoli et al., 2014) and found that using seedlings has a positive effect on the crop stand and shortens the time to harvest by 2-3 wk. However, only limited data is available on sweet corn yield and its response to the impact of different environmental conditions. Sweet corn is also sown in Bosnia and Herzegovina in the early spring, but no information is available regarding the yield and use of the seedlings. Therefore, the objective of this work was to determine the impact of transplanting and direct sowing on the productive properties, earliness, and supply extension of sweet corn under the environmental conditions of Bosnia and Herzegovina.

\section{MATERIALS AND METHODS}

The research was conducted during two different growing seasons (2018 and 2019) at the Butmir experimental field of

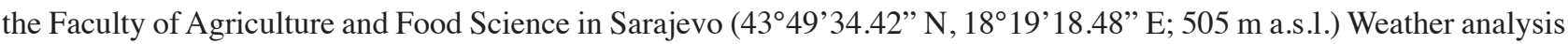
was performed based on data of a meteorological station in Bjelave (Sarajevo) located $10 \mathrm{~km}$ from the field experiment (FHMZ, 2019).

The sweet corn (Zea mays L. var. saccharata [Sturtev.] L.H. Bailey) hybrid 'Gold Cup' was used in the research. The treatments had a combination of two factors viz. two different cultivation technologies (transplanting and direct sowing) and two different sowing periods (8 and 15 May during both growing seasons). Sowing and transplanting of sweet corn were accomplished manually. The seedlings for transplanting were used at the age of $19 \mathrm{~d}$ with four developed leaves. The experiment was set up in a randomised block design and was replicated four times. The size of a basic plot was $20.0 \mathrm{~m}^{2}$ (5.2 $\mathrm{m}$ long and $3.85 \mathrm{~m}$ wide).

\section{Growing seedlings}

The sweet corn seedlings for transplanting were grown in a greenhouse and raised in polystyrene containers using a commercial substrate, Klasmann Potgrond $\mathrm{H}$ (Deilmann $\mathrm{GmbH}$, Geeste, Germany). The dimensions of the nursery trays were $523.6 \times 314.5 \times 60 \mathrm{~mm}$. Each tray contained 104 cells (pots), each with a capacity of $32 \mathrm{~mL}$. The sweet corn was sown $19 \mathrm{~d}$ before transplantation.

\section{Site preparation and crop management}

Before the experiment was set up, soil samples were collected at $0-20 \mathrm{~cm}$ depth for chemical analysis. A basic analysis of the chemical properties of the soil ( $\mathrm{pH}$, humus, $\mathrm{P}_{2} \mathrm{O}_{5}$, and $\mathrm{K}_{2} \mathrm{O}$ ) was conducted in the laboratory of the Faculty of Agriculture and Food Sciences in Sarajevo. Soil fertilisation conditions were the same in both years. Fertilisation was split into two applications: fertiliser at a rate of $300 \mathrm{~kg} \mathrm{ha}^{-1}$ (NPK 15:15:15) was applied with deep ploughing prior to sowing, and the rest of $\mathrm{N}\left(100 \mathrm{~kg} \mathrm{ha}^{-1}\right)$ was given at the stage of 5-7 leaves. Weeding and harvesting were accomplished manually. The ears were harvested at the milk stage.

\section{Data collection and statistical methods}

All data were recorded upon the harvesting period. Plant height $(\mathrm{cm})$ was measured from the soil surface for 10 randomly selected plants per plot. The number of plants per hectare was determined from the total number of plants per basic plot $\left(20 \mathrm{~m}^{2}\right)$. Measurements of the de-husked ear length were made on 10 randomly selected ears per plot $(\mathrm{cm})$. Ear mass (without husks) (g) was measured in 10 replicates per basic plot using a field scale. The yield per hectare was calculated based on the yield per basic plot $\left(20 \mathrm{~m}^{2}\right)$, which was calculated based on the mass and number of ears per plot. The optimum harvest time was determined by the daily control of the growth stage of sweet corn.

All the experimental measurements were statistically elaborated with the use of ANOVA at a level of significance of up to 0.05 . Statistical analyses were performed using the SPSS 22.0 software program (IBM, Armonk, New York, USA). 


\section{RESULTS}

The weather conditions during the research period differed from those during the reference period (1961-1990) (Figure 1). In 2018, above-average temperatures and rainfall were recorded throughout the growing season. The largest amount of rainfall in the first year of research was registered after experiment set-up. Rainfall throughout this period created such problems as a soil crust, which had a negative impact on sweet corn emergence. The amount of rainfall in the second year of research (2019) was approximately equal to that of the reference period. However, the average monthly temperatures differed from those recorded during the reference period. Lower-than-average temperatures were recorded during the first part of the crop cycle (May), while above-average temperatures were recorded in the second part of the crop cycle. A particularly warm period was recorded in August, when the air temperature was higher by $3.4^{\circ} \mathrm{C}$ compared to that of the climate reference period.

The cultivation technology significantly affected the evaluated parameters except plant height in 2018 (Table 1). The highest plant height ( $2 \mathrm{yr}$ average) was recorded in sweet corn crops cultivated with direct sowing $(182.6 \mathrm{~cm})$ compared with the transplanted crops $(175.4 \mathrm{~cm})$. In the $2 \mathrm{yr}$ period, the largest number of plants per hectare was recorded among

Figure 1. Average monthly temperature and rainfall.

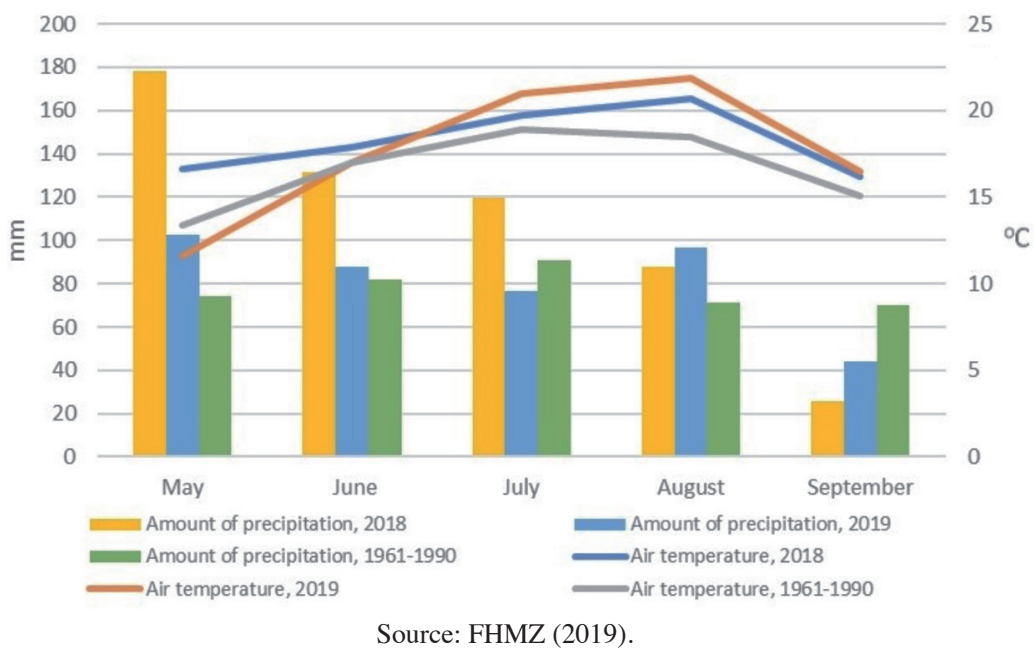

Table 1. Effect of transplanting and direct sowing on plant height, number of plants per hectare, ear length, ear mass and yield during 2018 and 2019 experimental year at Butmir.

\begin{tabular}{|c|c|c|c|c|c|c|c|c|c|c|}
\hline & \multirow[b]{2}{*}{$\begin{array}{c}\text { Sowing } \\
\text { time }\end{array}$} & \multicolumn{3}{|c|}{ Year 2018} & \multicolumn{3}{|c|}{ Year 2019} & \multicolumn{3}{|c|}{ 2-yr average } \\
\hline & & $\begin{array}{c}\text { Direct } \\
\text { sowing }\end{array}$ & Transplanting & Average & $\begin{array}{c}\text { Direct } \\
\text { sowing }\end{array}$ & Transplanting & Average & $\begin{array}{c}\text { Direct } \\
\text { sowing }\end{array}$ & Transplanting & Average \\
\hline \multirow[t]{3}{*}{ Plant height, $\mathrm{cm}$} & First & 188.7 & 173.2 & $181.0 \mathrm{~ns}$ & 178.7 & 176.9 & $177.8 \mathrm{a}$ & 183.7 & 175.1 & $179.4 \mathrm{~ns}$ \\
\hline & Second & 193.9 & 181.6 & $187.8 \mathrm{~ns}$ & 169.1 & 169.9 & $169.5 b$ & 181.5 & 175.8 & $178.6 \mathrm{~ns}$ \\
\hline & Average & $191.3 \mathrm{a}$ & $177.4 \mathrm{~b}$ & & $173.9 \mathrm{~ns}$ & $173.4 \mathrm{~ns}$ & & $182.6 \mathrm{~ns}$ & $175.4 \mathrm{~ns}$ & \\
\hline \multirow{3}{*}{$\begin{array}{l}\text { Number of plants } \\
\text { per hectare }\end{array}$} & First & 30833 & 45125 & 37979ns & 30125 & 49875 & $40000 \mathrm{~ns}$ & 30479 & 47500 & 38989ns \\
\hline & Second & 31250 & 46250 & $38750 \mathrm{~ns}$ & 28500 & 43500 & $36000 \mathrm{~ns}$ & 29875 & 44875 & $37375 \mathrm{~ns}$ \\
\hline & Average & $31041 b$ & $45687 \mathrm{a}$ & & $29312 b$ & $46687 a$ & & $30177 b$ & $46187 a$ & \\
\hline \multirow[t]{3}{*}{ Ear length, cm } & First & 21.9 & 22.3 & $22.1 \mathrm{~ns}$ & 21.2 & 22.5 & $21.8 \mathrm{~ns}$ & 21.5 & 22.4 & $22.0 \mathrm{~ns}$ \\
\hline & Second & 21.4 & 22.3 & $21.9 \mathrm{~ns}$ & 20.5 & 21.7 & $21.1 \mathrm{~ns}$ & 21 & 22 & $21.5 \mathrm{~ns}$ \\
\hline & Average & $21.6 \mathrm{~b}$ & $22.3 \mathrm{a}$ & & $20.8 b$ & $22.1 \mathrm{a}$ & & $21.2 b$ & $22.2 \mathrm{a}$ & \\
\hline \multirow[t]{3}{*}{ Ear mass, $\mathrm{g}$} & First & 301.8 & 306.3 & 304.0ns & 260.9 & 245.5 & $253.2 \mathrm{a}$ & 281.3 & 275.9 & $278.6 \mathrm{a}$ \\
\hline & Second & 297.3 & 305.8 & $301.5 \mathrm{~ns}$ & 221.1 & 254.4 & $237.8 b$ & 259.2 & 280.1 & $269.6 b$ \\
\hline & Average & $299.5 b$ & $306.0 \mathrm{a}$ & & $241.0 \mathrm{~ns}$ & $250.0 \mathrm{~ns}$ & & $270.3 b$ & $278.0 \mathrm{a}$ & \\
\hline \multirow[t]{3}{*}{ Yield, $\mathrm{t} \mathrm{ha}^{-1}$} & First & 5.8 & 11.6 & $8.7 \mathrm{~ns}$ & 10.6 & 11.3 & $10.9 \mathrm{~ns}$ & 8.2 & 11.4 & $9.8 \mathrm{~ns}$ \\
\hline & Second & 3.8 & 13.0 & $8.4 \mathrm{~ns}$ & 10.2 & 10.8 & $10.5 \mathrm{~ns}$ & 7.0 & 11.9 & $9.5 \mathrm{~ns}$ \\
\hline & Average & $4.8 \mathrm{~b}$ & $12.3 \mathrm{a}$ & & $10.4 b$ & $11.0 \mathrm{a}$ & & $7.6 \mathrm{~b}$ & $11.7 \mathrm{a}$ & \\
\hline
\end{tabular}

Different letters indicate significant differences at the 0.05 level; ns: nonsignificant difference. 
the transplanting variants during the harvest. This variant had about $34 \%$ more plants per hectare compared with the direct sowing yield. The visual parameters of the ear (length and mass) were significantly dependent on the cultivation technologies and sowing time. Ear length and mass were higher in crops grown using the transplanting technique (22.2 $\mathrm{cm}$ and $278.0 \mathrm{~g}$, respectively) than in crops grown using direct sowing $(21.2 \mathrm{~cm}$ and $270.3 \mathrm{~g}$, respectively). A delayed sowing time also led to a decrease in ear mass and length. Notably, the longest and heaviest ears $(22.0 \mathrm{~cm}$ and $278.6 \mathrm{~g})$ were recorded among the crops grown during the first sowing period (8 May).

Cultivation technology significantly influenced sweet corn yield, while sowing time had no effect. The average values of $2 \mathrm{yr}$ yield ranged from $7.6 \mathrm{tha}^{-1}$ (direct sowing) to $11.7 \mathrm{t} \mathrm{ha}^{-1}$ (transplanting). Therefore, the transplanting variant had a yield higher by $4.1 \mathrm{t} \mathrm{ha}^{-1}$ than the direct sowing variant. Similar effects of the cultivation technologies and sowing time were recorded during the research (2018 and 2019).

The simple correlation coefficient between the researched properties is shown in Table 2. These results show a positive correlation between the yield and the number of plants per hectare $(r=0.499)$. The correlation coefficients also indicate that the ear mass had the highest positive correlation with plant height $(r=0.525)$ as well as a significant positive correlation with ear length $(\mathrm{r}=0.428)$. Cultivation technology and sowing time influenced the earliness of the sweet corn harvest period (Table 3). In 2018, the transplanting variants had earlier harvests by 18 and $16 \mathrm{~d}$ in the first and second sowing periods, respectively, compared to the direct sowing variants. In 2019, the transplanting variants were harvested on 7 August (first sowing period) and on 12 August (second sowing period), 9 and $6 \mathrm{~d}$ earlier than the direct sowing variants, respectively.

Table 2. Coefficients of linear correlation between plant height, number of plants per hectare, ear length, ear mass and yield of sweet corn.

\begin{tabular}{lccccc}
\hline & Plant height & $\begin{array}{c}\text { Number of } \\
\text { plants per hectare }\end{array}$ & Ear length & Ear mass & Yield \\
\hline Plant height & 1 & & & & \\
Number of plants per hectare & -0.166 & 1 & & & \\
Ear length & 0.144 & $0.574^{* *}$ & 1 & & \\
Ear mass & $0.525^{* *}$ & 0.168 & $0.428^{*}$ & 1 & \\
Yield & $-0.540^{* *}$ & $0.499^{* *}$ & 0.337 & -0.177 & 1 \\
\hline
\end{tabular}

*,**Significant at the 0.05 and 0.01 levels, respectively.

Table 3. Dates of ear harvest and duration of crop cycle of sweet corn depending on cultivation technology.

\begin{tabular}{|c|c|c|c|c|c|c|c|}
\hline \multirow[b]{2}{*}{$\begin{array}{l}\text { Cultivation } \\
\text { technology }\end{array}$} & \multirow[b]{2}{*}{$\begin{array}{l}\text { Sowing } \\
\text { time }\end{array}$} & \multicolumn{3}{|c|}{ Year 2018} & \multicolumn{3}{|c|}{ Year 2019} \\
\hline & & $\begin{array}{l}\text { Time of } \\
\text { sowing/transplanting } \\
\text { in field }\end{array}$ & $\begin{array}{c}\text { Harvest } \\
\text { time }\end{array}$ & Days & $\begin{array}{l}\text { Time of } \\
\text { sowing/transplanting } \\
\text { in field }\end{array}$ & $\begin{array}{c}\text { Harvest } \\
\text { time }\end{array}$ & Days \\
\hline Direct & First & 8 May & 12 Aug & 96 & 8 May & 16 Aug & 100 \\
\hline sowing & Second & 15 May & 15 Aug & 89 & 15 May & 18 Aug & 92 \\
\hline Transplanting & First & 8 May & $25 \mathrm{Jul}$ & 78 & 8 May & 7 Aug & 91 \\
\hline of seedlings & Second & 15 May & $30 \mathrm{Jul}$ & 76 & 15 May & $12 \mathrm{Aug}$ & 89 \\
\hline
\end{tabular}




\section{DISCUSSION}

The resulting plant height suggests two things. First, plant height of the direct sowing variant was higher than plant height of the transplantation variant. This is in accordance with Adesina et al. (2014), who reported that after transplantation of sweet corn, physiological changes in the root are reflected in the growth of the vegetative mass of the plant. Second, plant height decreases with delayed sowing time, which has also been recorded in previous research (Williams, 2008; Rosa, 2014; Ugur and Maden, 2015), this is because of the shorter period available for absorbing solar radiation, which affects the formation of vegetative mass.

Although both variants of the field experiment were created with the same number of plants per hectare (seed and seedling), a significant difference was recorded at harvest. Missing plants in the field is a normal phenomenon, if within the normal range. According to Di Benedetto and Rattin (2008), this range can reach up to 15\%, and any increase over this limit has a negative impact on yield. In both years, the recorded plant density among the transplant variants was within the normal range. However, the direct sowing variants had significantly more missing plants, which suggests that these variants were under abiotic stresses. During the first year, excessive rain at the beginning of the growing season caused abiotic stress - that is, created soil crusts, which cause problems such as seedling emergence reduction (Amezketa et al., 2003; Wu et al., 2018). The main reason for a large number of missing plants among the direct sowing variants in the second year was low temperature. In Butmir, the low temperature during the beginning of May is one of the most important abiotic factors which affects corn germination. Low temperature during germination results in poor seed emergence, which is reflected in the form of reduced plant density (Rymen et al., 2007; Kara and Atar, 2013; Céccoli et al., 2014; Mao et al., 2017).

While cultivation technology and sowing date did not significantly affect ear parameters during both years of research, the results suggest that ear parameters were better in the transplant variant and visual parameters of the ear were better in the first sowing period. Dekhane and Dumbre (2017) also confirmed these findings in sweet corn, stating that among different sowing periods, maximum ear length and mass were obtained during the first sowing period. Similarly, Khan et al. (2018) found that yield components such as ear mass decline if the sowing time is delayed; they explained this by using a shorter period for plant growth, which reduced photosynthates.

The average yield of the transplantation variant was higher than that of the direct sowing variant, which suggests that the former produces a more stable yield. The main reason for this is the large number of plants per hectare. This observation can be confirmed with a positive correlation found between yield and number of plants per hectare. This finding is consistent with those of many other authors (Ugur and Maden, 2015; Lykhovyd, 2019) who reported that the number of plants per hectare is a major factor affecting sweet corn yield. On the other hand, when comparing the results of different sowing periods in this research, sowing time did not influence sweet corn yield. This observation differs from those previously reported, where sowing time was reported to significantly affect sweet corn yield (Ugur and Maden, 2015; Franco et al., 2016). The differences in yield reported in these studies might be due to the differences in environmental conditions and sowing times.

The results obtained from this research indicated that cultivation technologies and sowing time affect harvest time. Generally, during both years of study, the use of seedlings shortened the growing period to harvest, which was to be expected as the seedlings had the advantage of $18 \mathrm{~d}$ from the greenhouse. This finding is consistent with that of $\mathrm{Di}$ Benedetto and Rattin (2008), who reported that transplantation has a positive effect on the earliness of sweet corn harvest. After a comparison of the years of research, cultivation technologies and sowing date were found to differently affect harvest time. For instance, in 2019, the harvest dates were close, which can be explained by different weather conditions throughout the year. In 2019, after sowing in May, the low temperature slowed the growth of sweet corn. After the cold period, an above-average warm period occurred in June, which accelerated the growth of both corn variants used in the research. According to Franco et al. (2016), temperature is a major factor in corn growth and development, and low temperature slows down the process of photosynthesis.

In this research, different cultivation technologies impacted the research parameters. However, the sowing times had little or no effect on the parameters studied and had been selected based on the usual practice, which is, for Butmir from May 5 to 15 . However, this approach to selecting the sowing time is a limitation because it does not provide results on the effect of various cultivation technologies beyond the usual sowing time. Another limitation of this research is the use of only one variety of sweet corn as different varieties respond differently to environmental conditions. 
The use of seedlings in this research has some benefits compared to direct sowing, and these advantages can be used in practice. Moreover, the benefits of using seedlings may be particularly pronounced in environmental conditions where problems with achieving the optimum plant density and yield abound, which is common where the soil is cold during sowing. Also, this cultivation technology can be used to achieve an early harvest when the ear has a higher price in the market.

This research has exhibited the advantage of using seedlings and their effect on yield stability and the earliness of sweet corn harvest. However, further research should be conducted to observe the impact of using seedlings of different varieties on the productive properties and harvest earliness of sweet corn. In addition to this, future research should investigate the impact of transplantation on the nutritional value of sweet corn and its economic benefits.

\section{CONCLUSIONS}

According to this research, different cultivation technologies significantly affect the evaluated parameters. Plant population was 34\% greater in transplanted than in directly sown crops because of abiotic stress. Low temperatures and soil crusts negatively affected the germination of sweet corn and reduced plant population in directly sown crops. Differences in plant population caused differences in ear yield, and therefore, the transplant variant had a $4.1 \mathrm{t} \mathrm{ha}^{-1}$ higher yield than direct sowing. Furthermore, the use of seedlings can positively affect ear length and mass. Conclusively, the results of this study proved that the use of seedlings has a positive effect on harvest earliness, which extended the supply of fresh sweet corn beyond the conventional season by up to $18 \mathrm{~d}$.

\section{ACKNOWLEDGEMENTS}

We would like to thank the Federal Hydrometeorological Institute in Sarajevo for providing the data that contributed to the publication of this work.

\section{REFERENCES}

Adesina, J.M., Agbaje, O.G., Aderibigbe, T.B., and Eleduma, F. 2014. Effect of transplanting age on vegetative and root development of maize (Zea mays L.) in South Western Nigeria. World Rural Observe 6(1):1-4.

Aguyoh, J., Taber, H.G., and Lawson, V. 1999. Maturity of fresh market sweet corn with direct-seeded plants, transplants, clear plastic mulch, and row cover combinations. HortTechnology 9:420-425. https://doi.org/10.21273/horttech.9.3.420.

Alan, O., Kinaci, G., Kinaci, E., Basciftci, Z.B., Sonmez, K., Evrenosoglu, Y., et al. 2014. Kernel quality of some sweet corn varieties in relation to processing. Notulae Botanicae Horti Agrobotanici Cluj-Napoca 42(2):414419. https://doi.org/10.1583/nbha4229425.

Amezketa, E., Aragües, R., Pérez, P., and Bercero, A. 2003. Techniques for controlling soil crusting and its effect on corn emergence and production. Spanish Journal of Agricultural Research 1(1):101-110. https://doi .org/10.5424/sjar/2003011-13.

Andonova, P. 2014. Yield increase as influenced by transplanting of sweet maize (Zea mays L. saccharata). American Journal of Experimental Agriculture 4(11):1314-1329. https://doi.org/10.9734/ajea/2014/11077.

Budak, F., and Aydemir, S.K. 2018. Grain yield and nutritional values of sweet corn (Zea mays var. saccharata) in produced with good agricultural implementation. Nutrition and Food Science International Journal 7(2):1-5. https://doi.org/10.19080/NFSIJ.2018.07.555710.

Céccoli, G., Ortega, L., Gariglio, N., Favaro, J., and Bouzo, C. 2014. Sweet corn (Zea mays L.) growth and yield are influenced by establishment methods. Bothalia Journal, National Botanical Institute 44(6):2-12.

Dekhane, S.S., and Dumbre, R.B. 2017. Influence of different sowing dates on plant growth and yield of hybrid sweet corns. Advance Research Journal of Crop Improvement 8(2):191-194. https://doi.org/10.15740/has/arjci/8.2/191-194.

Di Benedetto, A., and Rattin, J. 2008. Transplant in sweet maize: A tool for improving productivity. The Americas Journal of Plant Science and Biotechnology 2(2):96-108.

El-Hamed, K., Elwan, M., and Shaban, W. 2012. Enhanced sweet corn propagation: Studies on transplanting feasibility and seed priming. Vegetable Crops Research Bulletin 75:31-50. https://doi.org/10.2478/v10032-011-0016-4.

FHMZ. 2019 . Federal Hydrometeorological Institute (FHMZ), Sarajevo, Bosnia and Her z e g o vi n a . http://www.fhmzbih.gov.ba/latinica/index.php.

Franco, A.A.N., Filho, P.S.V., Scapim, C.A., Okumura, R.S., Marques, O.J., and Numoto, A.Y. 2016. Effect of sowing time on the growth and yield of sweet corn (Zea mays L.) cultivated during fall-winter period in subtropical climate. Australian Journal of Crop Science 10:831-841. https://doi.org/10.21475/ajcs.2016.10.06.p7460. 
Hacisalihoglu, G., Kantanka, S., Miller, N., Gustin, J.L., and Mark, S.A. 2018. Modulation of early maize seedling performance via priming under sub-optimal temperatures. PLOS ONE 13(11):1-13. https://doi.org/10.1371/journal.pone.0206861.

Hassell, R.L., Dufault, R.J., and Phillips, T.L. 2003. Low-temperature germination response of su, se, and $\mathrm{sh}_{2} \mathrm{sweet} c \mathrm{corn}$ cultivars. HortTechnology 13(1):136-141. https://doi.org/10.21273/horttech.13.1.0136.

Heshemi, N., Seyed, M., Omid, A., Bahram, A., Mohammad, B., and Mansour E.B. 2017. The effects of drought and heat stress on some physiological and agronomic characteristics of new hybrids of corn in the north of Khuzestan Province (Iran). EurAsian Journal of BioSciences 11:32-36.

Kara, B., and Atar, B. 2013. Effects of mulch practices on fresh ear yield and yield components of sweet corn. Turkish Journal of Agriculture and Forestry 37(3):281-287. https://doi.org/10.3906/tar-1206-48.

Khan, A.A., Hussain, A., Zoor, M., Ganai, A., Rashid, Z., and Dar, A.Z. 2018. Response of sweet corn hybrid to transplanting dates and nitrogen levels under temperate conditions. International Journal of Current Microbiology and Applied Sciences 7(4):1284-1291. https://doi.org/10.20546/ijcmas.2018.704.143.

Lykhovyd, P. 2019. Sweet maize yield structure depending on cultivation technology under the drip-irrigated conditions. Polish Journal of Natural Sciences 34(2):175-184.

Mao, J., Yu, Y., Yang, J., Li, G., Li, C., Qi, X., et al. 2017. Comparative transcriptome analysis of sweet corn seedlings under low-temperature stress. Crop Journal 5(5):396-406. https://doi.org/10.1016/j.cj.2017.03.005.

Rattin, J., Molinari, J., Giardina, E., and Di Benedetto, A. 2018. Tools for improving sweet corn yield. International Journal of Advances in Agriculture Sciences 3(10):1-14.

Rosa, R. 2014. Response of sweet corn cultivated in eastern Poland to different sowing dates and covering with non-woven PP. Part II. Ear quality traits. Acta Scientiarum Polonorum, Agricultura 13(4):113-126.

Rymen, B., Fiorani, F., Kartal, F., Vandepoele, K., Inzé, D., and Beemster, G.T.S. 2007. Cold nights impair leaf growth and cell cycle progression in maize through transcriptional changes of cell cycle genes. Plant Physiology 143(3):1429-1438. https://doi.org/10.1104/pp.106.093948.

Tabakovic, M., Simic, M., Stanisavljevic, R., Milivojevic, M., Secanski, M., and Postic, D. 2020. Effects of shape and size of hybrid maize seed on germination and vigour of different genotypes. Chilean Journal of Agricultural Research 80:381-392. https://doi:10.4067/S0718-58392020000300381.

Ugur, A., and Maden, H.A. 2015. Sowing and planting period on yield and ear quality of sweet corn (Zea mays L. var. saccharata). Ciência e Agrotecnologia 39(1):48-57. https://doi.org/10.1590/s1413-70542015000100006.

Welbaum, G.E., Frantz, J.M., Gunatilaka, M.K., and Shen, Z. 2001. A comparison of the growth, establishment, and maturity of direct-seeded and transplanted $s h_{2}$ sweet corn. HortScience 36(4):687-690. https://doi.org/10.21273/hortsci.36.4.687.

Williams, M.M. 2008. Sweet corn growth and yield responses to planting dates of the North Central United States. HortScience 43(6):1775-1779.

Wu, H., Zhang, P., Chen, G., Pan, L., Li, J., and Dong, L. 2018. Environmental factors on seed germination and seedling emergence of Phleum paniculatum Huds. Chilean Journal of Agricultural Research 78:370-377. https://doi:10.4067/S0718-58392018000300370. 